\title{
Energy R\&D in the United States
}

\author{
JJ Dooley
}

April 1999

Prepared for

U.S. Department of Energy

under Contract DE-AC06-76RLO 1830

Pacific Northwest National Laboratory

Operated for the U.S. Department of Energy

by Battelle Memorial Institute

RECEVED

AUG 231899

Battelle

OSTI 


\title{
DISCLAIMER
}

This report was prepared as an account of work sponsored by an agency of the United States Government. Neither the United States Government nor any agency thereof, nor Battelle Memorial Institute, nor any of their employees, makes any warranty, express or implied, or assumes any legal liability or responsibility for the accuracy, completeness, or usefulness of any information, apparatus, product, or process disclosed, or represents that its use would not infringe privately owned rights. Reference herein to any specific commercial product, process, or service by trade name, trademark, manufacturer, or otherwise does not necessarily constitute or imply its endorsement, recommendation, or favoring by the United States Government or any agency thereof, or Battelle Memorial Institute. The views and opinions of authors expressed herein do not necessarily state or reflect those of the United States Government or any agency thereof.

\author{
PACIFIC NORTHWEST NATIONAL LABORATORY \\ operated by \\ BATTELLE MEMORIAL INSTITUTE \\ for the \\ UNITED STATES DEPARTMENT OF ENERGY \\ under Contract DE-AC06-76RLO 1830
}




\section{DISCLAIMER}

Portions of this document may be illegible in electronic image products. Images are produced from the best available original document. 
ASTRACT: In 1997, the US public and private sectors invested $\$ 205.7$ billion in R\&D. Private sector investments in R\&D increased 34\% between 1990 and 1997; over the same period the federal government decreased its expenditures by $15 \%$ in real terms. Projections of outyear federal budgets indicate the federal government will continue to reduce its investments in $R \& D$ for the foreseeable future. Defense R\&D continues to be the largest area of concentration for federal government's R\&D investments, with defense R\&D accounting for $54 \%$ of all federal $R \& D$ outlays in 1998. Defense $R \& D$ is funded at a level which is there times higher than health $R \& D$. Health $R \& D$ has experienced the largest inflation-adjusted increases of any federal $R \& D$ program, up $21 \%$ in real terms since 1990.

US national (i.e., public and private) investments in energy R\&D currently stand at a 23-year low of $\$ 4.4$ billion in 1996. Federal support for energy R\&D has declined $22 \%$ in real terms between 1990 and 1996. Federal energy R\&D investments are also undergoing changes in priority. Fossil energy $R \& D$ programs are at the beginning of a potentially significant change away from "clean coal" technology development programs and towards more fundamental research on ways to decarbonize fossil fuels and sequester carbon dioxide. The federal nuclear energy R\&D program has restarted (at a modest level) research to develop new reactor concepts after many years of no federal research in this area. The United States has withdrawn from the ITER project, calling into question the viability of this international fusion energy program. Renewable energy and energy efficiency $R \& D$ programs continue to be the only consistent areas of growth in the federal energy R\&D budget.

KEY WORDS: Energy R\&D, the United States, climate change 


\section{United States}

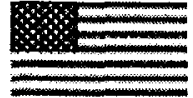

Population: $267,954,764$ (July 1997 est.)

GDP 1996: $\$ 7.61$ trillion (1996 est.) $)^{2}$

R\&D as a percent of GDP $=2.55 \%^{3}$

National R\&D Effort 1996

- $\$ 193$ billion

- $32.5 \%$ of which was supported by the public sector

- $62.7 \%$ of which was supported by the

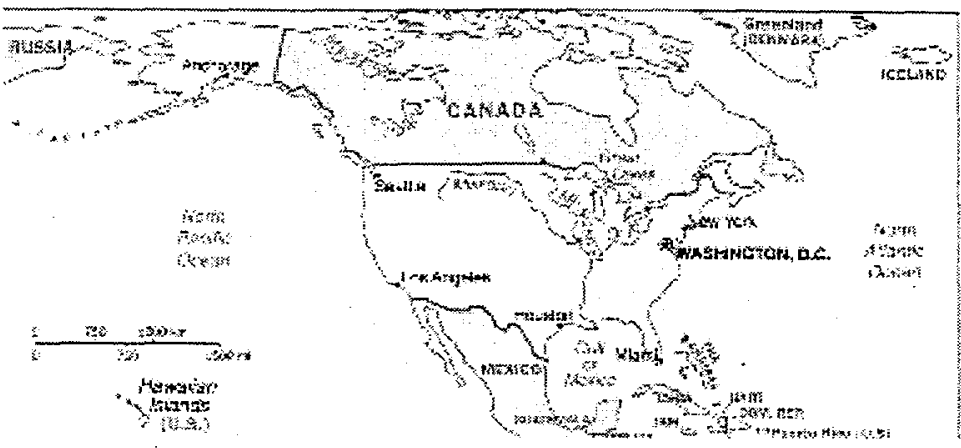
private sector

\section{National Energy R\&D Effort 1996:}

- $\$ 4.4$ billion $^{\mathrm{a}}$

- $43.6 \%$ of which was supported by the private sector

- $56.4 \%$ of which is supported by the public sector

Chapter Overview:

Summary of Analytical Findings

National S\&T Funding \& Goals

National Energy Policy and Energy Overview

Energy R\&D Programs

\footnotetext{
a J.J. Dooley, US National lnvestments in Energy R\&D: 1974-1996 (PNNL-11788, Washington, DC: Pacific Northwest National Laboratory, December 1997). This research was requested by the White House Council of Economic Advisors and is published in the Economic Report of the President: 1998 (Washington, DC: Council of Economic Advisors, February 1998).
} 


\section{SUMMARY OF ANALYTICAL FINDINGS}

The 1990s have seen robust growth in US investments in R\&D; combined public and private sector expenditures for R\&D have increased 13\% in real terms from 1990 to 1997. In 1997, the US public and private sectors invested $\$ 205.7$ billion in R\&D. However, this growth in investments in $R \& D$ is present only in the private sector. Private sector investments in R\&D increased 34\% between 1990 and 1997; over the same period the federal government decreased its expenditures by $15 \%$ in real terms. Projections of outyear federal budgets indicate the federal government will continue to reduce its investments in $R \& D$ for the foreseeable future.

A significant trend that has emerged in the 1990s in industry's R\&D effort has been the dramatic increase in the portion of industrial R\&D supported by non-manufacturing (i.e., service) industries. The non-manufacturing sector now accounts for more than $25 \%$ of all industrially supported R\&D in the United States.

Defense R\&D continues to be the largest area of concentration for federal government's R\&D investments. Since 1986, the proportion of all federal R\&D funds going to defense R\&D has been in steady decline, dropping from its peak of $69 \%$ in 1986 to $54 \%$ of all federal R\&D outlays in 1998. Despite this decline in defense $R \& D$ and the rapid rise in health $R \& D$ since the early 1990 s, defense $R \& D$ will still be funded at a level which is three times higher than health $R \& D$. Health R\&D (mainly carried out by the National Institutes of Health) has experienced the largest inflation-adjusted increases, up $21 \%$ in real terms since 1990 , of any federal R\&D program. AIDS-related research and cancer-related research now account for nearly $30 \%$ of all US health $R \& D$ investments. The US government's investments in energy R\&D have experienced the largest reductions in the 1990 s. Federal support for energy R\&D has declined $22 \%$ in real terms between 1990 and 1996.

The two most significant energy policy issues facing the United States at this time are the movement towards a deregulated electric utility industry and the question of what should be done to control US emissions of greenhouse gases. To a large extent, these two issues are being debated separately although there appear to be many interconnections between the two.

US national (i.e., public and private) investments in energy $R \& D$ currently stand at a 23 -year low of $\$ 4.4$ billion in 1996 . The peak year for energy $R \& D$ investments was 1980 , when investments in energy $R \& D$ reached $\$ 11.6$ billion. The ongoing deregulation of the electric and natural gas utility industry in the United States is responsible, along with lower energy prices, for a significant downturn in the private sector's support for energy R\&D.

Federal investments in energy R\&D have declined 22\% in real terms between 1990 and 1996. Federal energy $R \& D$ investments are also undergoing changes in priority. Fossil energy R\&D programs are at the beginning of a potentially significant change away from "clean coal" technology development programs and towards more fundamental research on ways to decarbonize fossil fuels and sequester carbon dioxide. The federal nuclear energy R\&D program has restarted (at a modest level) research to develop new reactor concepts after many years of no federal research in this area. The United States has withdrawn from the ITER project, calling into question the viability of this international fusion energy program. Renewable energy and energy efficiency $R \& D$ programs continue to be the only consistent areas of growth in the federal energy R\&D budget. 


\section{UNITED STATES NATIONAL SCIENCE AND TECHNOLOGY EFFORT}

As Figure 1 shows, US investments in R\&D for the first time exceeded $\$ 200$ billion dollars (in current dollars) in 1997. Total R\&D spending in the US reached $\$ 205.7$ billion in $1997 .^{5}$ In 1997 , the total private sector investment in $R \& D$ was $\$ 133.3$ billion, while the federal government's R\&D investments in 1997 totaled $\$ 62.7$ billion (in current dollars).

Figure 1: US National S\&T Effort 1985-1997

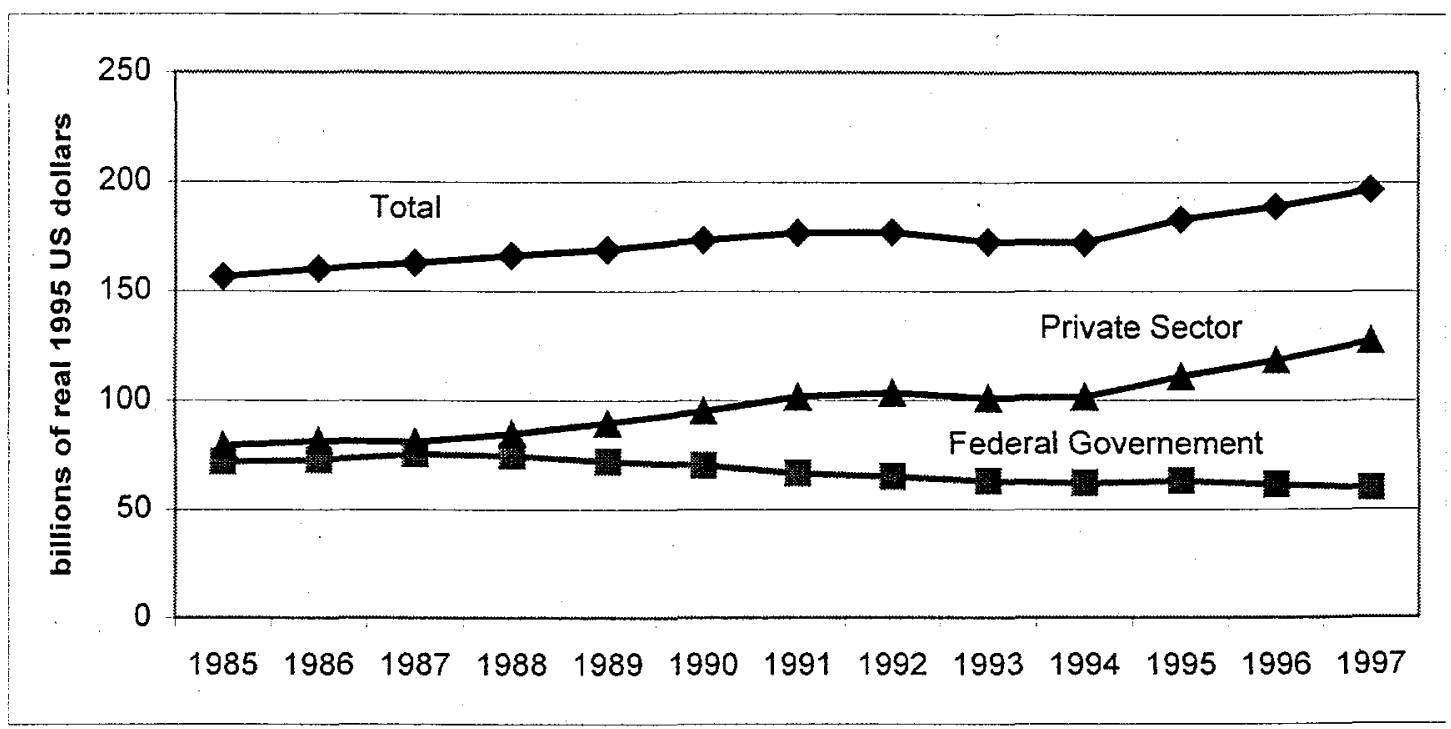

Figure 1 shows that industrial investments in $R \& D$ are responsible for the current expansion in US R\&D spending. Federal investments in $R \& D$ have been declining at an average annual rate of $2.2 \%$ since 1987 . Between 1987 and 1997, federal investments in R\&D decreased by over $20 \%$ in real terms. On the other hand, industrial R\&D in the US increased in real terms $57.1 \%$ over the same period. The average rate of real growth in industrial R\&D over the past decade was $4.7 \% .^{8}$ While federal R\&D investments actually declined in the 1990 s (in both nominal and real terms), it is important to note that industrial $R \& D$ investments have increased (at least in nominal terms) every year since 1953 .

The strong growth in industrial $R \& D$ investments is in large measure attributable to the strength of the US economy in the 1990s. It is also likely attributable to the growing realization in firms that the structural and operational changes made in the 1980s and early 1990 s (e.g., corporate mergers, downsizing, outsourcing) are unlikely to provide a basis for continuing growth by themselves. That is, firms see investments in R\&D increasingly as the key to their long-term prosperity and survival. ${ }^{10}$ Increased industrial investments in R\&D resulting from concerns for long-term growth do not signal a greater willingness on the part of US industry to fund longer term basic research. The US private sector continues to assign relatively little priority $(5-7 \%$ of all R\&D) to basic research. ${ }^{11}$

A very important trend in industry's $R \& D$ effort has been the dramatic increase in the nonmanufacturing (i.e., service) sector's R\&D effort. Between 1983 and 1993, non-manufacturing firms have increased their R\&D investments by more than $900 \%$. It is now estimated that the non-manufacturing sector currently accounts for more than $25 \%$ of the industrially supported 
$R \& D$ in the United States. Computer software, $R \& D$ and testing laboratories, and communication service firms are important $R \& D$ players in this sector. ${ }^{12}$

These divergent trends of growth in private sector $R \& D$ investments while the public sector steadily loses ground in real terms is a further manifestation of a trend that began in 1978. Up until 1978, the federal government funded the majority of the US R\&D effort; however, since 1978 the percent funded by the federal government has been in steady decline. The end of the Cold War with its decreasing public sector investments in defense R\&D has only accelerated this general trend. The US government accounted for less than a third of all R\&D investments in the United States in 1996.

In order to attempt to reverse the slide in the federal government's support for R\&D, two pieces of legislation have been introduced in the US Senate to effectively double US federal investments in $R \& D$ within the next 10 to 12 years. To be more precise, the legislation intends to double US investments in civilian (i.e., non-defense) $R \& D$. Given that the proposed legislation are authorization bills, the money needed to affect this doubling is still subject to annual appropriations bills and those bills will still be subject to the demand to reduce federal spending and to meet other national needs. If nothing else, the two bills signal an awareness that US federal investments in non-defense $R \& D$ have been in decline for more than a decade and that this decline could have a negative impact on the nation's continued prosperity. ${ }^{13}$

On the other hand, projections of outyear federal budgets seem to indicate that the federal government will be investing less and not more in $\mathrm{R} \& \mathrm{D}$ for the foreseeable future. For example, the American Association for the Advancement of Science projects that from FY1999 to FY2004 the federal government will cut its overall investments in $R \& D$ by a further $10.4 \%$. These reduced investment levels in $R \& D$ are believed to be driven in large measure by the government's desire to improve the financing of Medicare and Social Security, which are seen as higher priorities than R\&D. ${ }^{14}$

As Figure 2 shows, the top six socioeconomic areas of R\&D investment (national defense, health, space, general science, energy, and natural resources and the environment) for the US government accounted for $94 \%$ of all federal R\&D outlays in $1996 .{ }^{15}$ Since 1986 , the proportion of all federal $R \& D$ funds going to defense $R \& D$ has been in steady decline, dropping from its peak of $69 \%$ in 1986 to the $54 \%$ of all federal R\&D outlays in 1998 . Despite this decline in defense $R \& D$ and the rapid rise in health $R \& D$ since the early 1990 s, defense $R \& D$ will still be funded at a level which is three times higher than health $R \& D .{ }^{16}$ Defense $R \& D$ is expected to continue receiving a decreasing portion of all federal R\&D outlays. ${ }^{17}$

Health R\&D (mainly carried out by the National Institutes of Health) has experienced the largest inflation-adjusted increases, up $21 \%$ in real terms since 1990 , of any federal R\&D program. AIDS-related research and cancer-related research now account for nearly $30 \%$ of all US health R\&D investments. ${ }^{18}$

Space-related R\&D has increased substantially in the early 1990 s $(+15 \%)$ although funding for this R\&D objective leveled off in 1995 and has been in decline since that time. Most of the increase in space related R\&D has been directed towards the development of the US-led International Space Station.

Funding for general science has remained flat during the 1990s even though these general science programs are looked upon very favorably by both the Congress and the Administration. The "general science" category of the US budget contains the research programs of the National 
Science Foundation and of the high energy and nuclear physics programs of the Department of Energy.

Figure 2: Major Socioeconomic Areas of US Federal R\&D Support 1996

\begin{tabular}{|cc|ccccc|}
\hline & 40 & & & & \\
\hline
\end{tabular}

Of the major socioeconomic areas of R\&D supported by the US government, "energy R\&D" has experienced the largest reductions in the 1990s. Federal support for energy R\&D has declined $22 \%$ in real terms between 1990 and 1996. The Department of Energy accounts for $94 \%$ of the funding in this area with the Tennessee Valley Authority and the Nuclear Regulatory Commission's research programs accounting for the remainder. ${ }^{19}$

The "natural resources and the environment" budget category contains the R\&D programs of the Environmental Protection Agency, the National Oceanic and Atmospheric Administration, and the other related programs housed within Departments that oversee the management of natural resources, such as the Forestry Service. Funding for R\&D in this area has increased $10 \%$ since 1990. 


\section{U.S. 1995 Total Energy Demand 88.3 Quads}
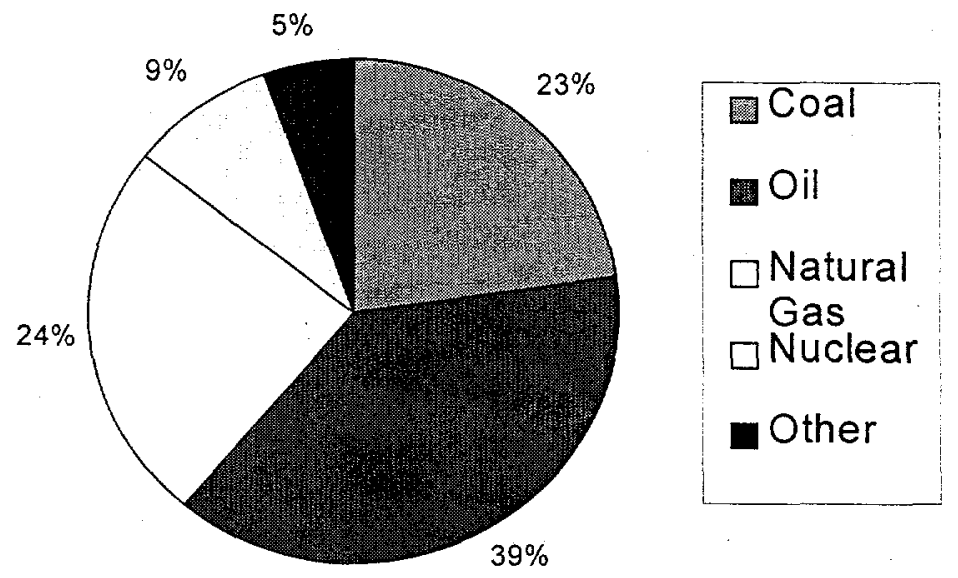

1997 Energy Snapshot ${ }^{20}$

\begin{tabular}{|l|l|}
\hline $\begin{array}{l}\text { Energy Consumption per Capita: 352 million } \\
\text { Btu }\end{array}$ & $\begin{array}{l}\text { Energy Related Carbon Emissions: 1,463 } \\
\text { million metric tons (24\% of world carbon } \\
\text { emissions) }\end{array}$ \\
\hline $\begin{array}{l}\text { "Kyoto Commitment": 7\% reduction from } \\
1990 \text { levels in GHG emissions by 2008-2012 }\end{array}$ & Carbon Emissions per Capita: 5.4 metric tons \\
\hline
\end{tabular}

Energy Policy: Perhaps the two most significant energy policy issues facing the United States at this time are the movement towards a deregulated electric utility industry and what, if anything, should be done to control US emissions of greenhouse gases (principally carbon dioxide). To a large extent these two issues are being debated separately though there appear to be many interconnections between the two. For example, the Clinton Administration claims that its Comprehensive Electricity Competition Plan will reduce greenhouse gas emissions by $25-40$ million metric tons of carbon equivalent. ${ }^{21}$ Others have pointed to evidence that suggests that utility restructuring has resulted in significant reductions (real decrease of $42 \%$ between 1985 1995 ) in the private sector's investments in energy R\&D and that these reductions will make it more difficult for the US to reduce its emissions of greenhouse gases. ${ }^{22}$

Utility Deregulation - The push to deregulate the US utility industry formally began with the passage of the Energy Policy Act of 1992 and the subsequent release of the April 24, 1996, Federal Energy Regulatory Commission Order Number 888, which required electric utilities to open their transmission systems to power generated by other companies. However, unlike the situation in many other nations, the process by which utility deregulation in the United States is being implemented is not being driven by any overarching national policy. Rather, for the time being, the direction and the pace for utility deregulation is largely being set by state-level decisions. 
At the national level, five major bills were introduced in the $105^{\text {th }}$ Session of Congress to "comprehensively" implement utility deregulation, and in March 1998 the Clinton Administration finalized its proposal to comprehensively deregulate the nation's utilities. ${ }^{b}$ In the context of the United States, "comprehensive" utility restructuring legislation would: (1) allow (and in some cases mandate) retail wheeling, i.e., allow customers to choose their electricity suppliers; (2) fundamentally reform and/or repeal various aspects of the Public Utility Regulatory Policies Act (PURPA) that guaranteed small generators and cogenerators of electricity a market for their electricity; and (3) seek to repeal aspects of the Public Utility Holding Company Act (PUHCA) which regulates financial transactions between companies that have interests in public utility companies. The six major legislative proposals differ significantly with respect to how utility deregulation should unfold across the United States. For example, these bills establish "dates certain" for full nationwide retail competition that vary from January 1, 1999, to January 1, 2003, while other bills do not specify a date, leaving that decision up to the individual states. The proposals also differ as to how "stranded costs" should be recovered and on the desirability of federal mandates for public benefit surcharges and renewable energy portfolio standards (both of which are designed to retain some of the "public benefit" programs that were supported by utilities when they were regulated).

Given so much uncertainty at the federal level on how utility restructuring should be carried out, for the time being the States have been allowed to set the pace of utility restructuring. Indeed, some states such as California, New York and New Hampshire are the forefront in rapidly pushing utility deregulation..$^{c}$ On March 31, 1998, California became the first State to completely deregulate its utilities and to allow all consumers to buy electric power from any supplier. However, owing to technical difficulties in implementing the law, deregulation and its hoped-for lower energy prices for consumers appears to be unfolding rather slowly in California. ${ }^{23}$ Many other states are, at least for the time being, slowing their push to deregulate utilities within their jurisdiction as they pause to observe how California will overcome the difficulties it has encountered in implementing its ambitious deregulation plans. Currently, 48 states and the District of Columbia have initiated some form of activity ranging from passing legislation and actually beginning the process of deregulation to asking the state regulatory body or other advisory boards to study whether and how the state should pursue utility deregulation. ${ }^{24}$

Climate Change -- The United States is the world's largest producer and consumer of energy. It is also the largest source of anthropogenic carbon emissions in the world. In June of 1992, the United States ratified an international treaty that formally committed itself to the stabilization of

\footnotetext{
${ }^{b}$ Sources for this overview of federal utility restructuring legislation include the following: Howard Buskirk, "Draft Administration Bill Gives FERC Sweeping New Deregulation Powers" (The Energy Daily 26 (95) May 20, 1998): 1-2; DOE's Legislative Proposal to Restructure the Utility Industry (Inside Energy /with Federal Lands May 18, 1998): 7; National Association of Regulatory Utility Commissioners, Electric Restructuring Legislation In the 105th Congress \& NARUC Principles: Issues Comparison (July 1997 http://www.naruc.org/legislat.htm; Larry Parker, Electricity: The Road toward Restructuring (Washington, DC: Congressional Research Service, Environment and Natural Resources Policy Division, October 14, 1997); Larry Parker, Electricity Restructuring: Comparison of S. 140I, H.R. 655, H.R. 1230, S. 722, and H.R. 1960 (Washington, DC: Congressional Research Service, Environment and Natural Resources Policy Division, November 17, 1997); United States Department of Energy's Energy Information Administration, The Restructuring of the Electric Power Industry: A Capsule of Issues and Event. (Washington, DC: February 10, 1998).

${ }^{c}$ For an up-to-date summary of utility deregulation initiatives at the state level, see US Department of Energy, Energy Information Agency, "Status of State Electric Utility Deregulation Activity as of August 1, 1998 (updated monthly)" (http://www.eia.doe.gov/cneaf/electricity/chg_str/tab5rev.html).
} 
US emissions of greenhouse gases by 2000 at their 1990 levels. Current projections indicate that the United States will be unable to meet this commitment given that its emissions of carbon (the principal greenhouse gas of concern) will reach 1,577 million metric tons in 2000, an increase of $18 \%$ (240 million metric tons) from the 1,337 million metric tons emitted in $19900^{25}$

There are three principal explanations behind the rise in US carbon emissions since 1990. First, because of the vigorous economic growth that has characterized much of the 1990s, energy consumption and therefore energy-related emissions have increased. Second, many of the gains in energy efficiency that were realized in the 1980s (caused in large measure by the oil price shocks of the previous decade) have started to peak and decline, e.g., low gasoline prices have encouraged many Americans to purchase less fuel efficient sport utility vehicles, minivans, and small trucks, all of which are less fuel efficient than small cars. Third, electricity production from the United States' two principal emissions-free energy sources, nuclear power and hydropower has stagnated since the early 1990 s, thus implying that the increasing energy demand has been met with by increasing reliance on fossil fuels. ${ }^{26}$

In December 1997 at the global warming summit in Kyoto, Japan, the US delegation agreed to reduce United States carbon emissions by 7\% from 1990 levels by 2008-2012. Many believe that it will be exceedingly difficult to meet this reduction. ${ }^{27}$ In order to attempt to meet this and previous emission reduction challenges, the Clinton Administration has announced a number of programs including the 1993 Climate Change Action Plan (a series of 44 actions designed to reduce emissions), the 1997 Million Solar Roofs Initiative (an initiative to install solar energy panels on 1 million roofs in the United States by 2010), and the 1998 Climate Change Technology Initiative (a $\$ 6.3$ billion package of $R \& D$, tax breaks and other incentives for the deployment of new technologies) designed to reduce US emissions of greenhouse gasses. ${ }^{28}$ For the most part, the US Congress has received these initiatives with some skepticism. This skepticism is in part based on a disagreement with the Administration as to how urgent and how severe the threat posed by climate change really is. Congress has scaled back many of the proposals the Clinton Administration has put forward to address climate change, which has conceivably reduced the hoped-for effectiveness of these programs as tools for reducing greenhouse gas emissions. One area in which there is some level of agreement between the two sides is on the need for further research to understand the science of climate change. 


\section{ANALYSIS OF ENERGY R\&D PROGRAMS}

As noted earlier in this report, US federal investments in energy R\&D have been in decline throughout the 1990s. This decline in federal energy R\&D actually began in 1979 when US federal investments in energy $R \& D$ peaked at $\$ 6.7$ billion dollars. US private sector investments in energy $R \& D$ peaked one year later in 1980 when they reached $\$ 5.2$ billion. US national (i.e., public and private) investments in energy $R \& D$ currently stand at a $23-y e a r$ low of $\$ 4.4$ billion in 1996 (see Figure 1). The peak year for energy R\&D investments was 1980 , when investments in energy $R \& D$ reached $\$ 11.6$ billion. $^{\mathrm{d}}$

A recently published analysis noted that underlying this reduction in the support of energy $R \& D$ in the United States is a pronounced shift away from the funding of long term "public good" or public benefit energy R\&D in the United States. This shift is particularly marked with respect to the private sector's support for energy $R \& D$. This analysis also showed that the push for energy market deregulation in the United States and lower energy prices was severely dampening the private sector's investments in energy $R \& D$. There also seems to be little prospect that the federal government will be able to significantly increase its funding for energy $R \& D$. The analysis concluded by pointing out that these trends of disinvestment and a focus on less risky near-term research would likely have a pronounced negative impact on US efforts to develop "cleaner, environmentally-preferred advanced energy supply" technologies. ${ }^{29}$

Reacting to trends such as those outlined above, President Clinton asked his Council of Advisors on Science and Technology (PCAST) to perform an assessment of the US energy R\&D effort. That assessment, Federal Energy Research and Development for the Challenges of the Twentyfirst Century, concluded that the United States is not currently investing enough nor investing in the right energy technologies to meet the opportunities and the challenges of the next century. The report, the most comprehensive study of federal energy R\&D carried out in recent years, urged that funding for energy R\&D be increased and recommended significant changes in emphasis in certain programs.

In this section of the report, trends within the US federal energy R\&D program will be discussed and an analysis of major energy R\&D programs supported by the federal government along with trends within these program elements will be presented.

\footnotetext{
d J.J. Dooley, US National Investments in Energy R\&D: 1974-1996 (PNNL-11788, Washington, DC: Pacific Northwest National Laboratory, December 1997). This research was requested by the White House Council of Economic Advisors and is published in Council of Economic Advisors, Economic Report of the President: 1998 (Washington, DC: February 1998).
} 
Figure 4: US National Investment in Energy R\&D 1974-1996

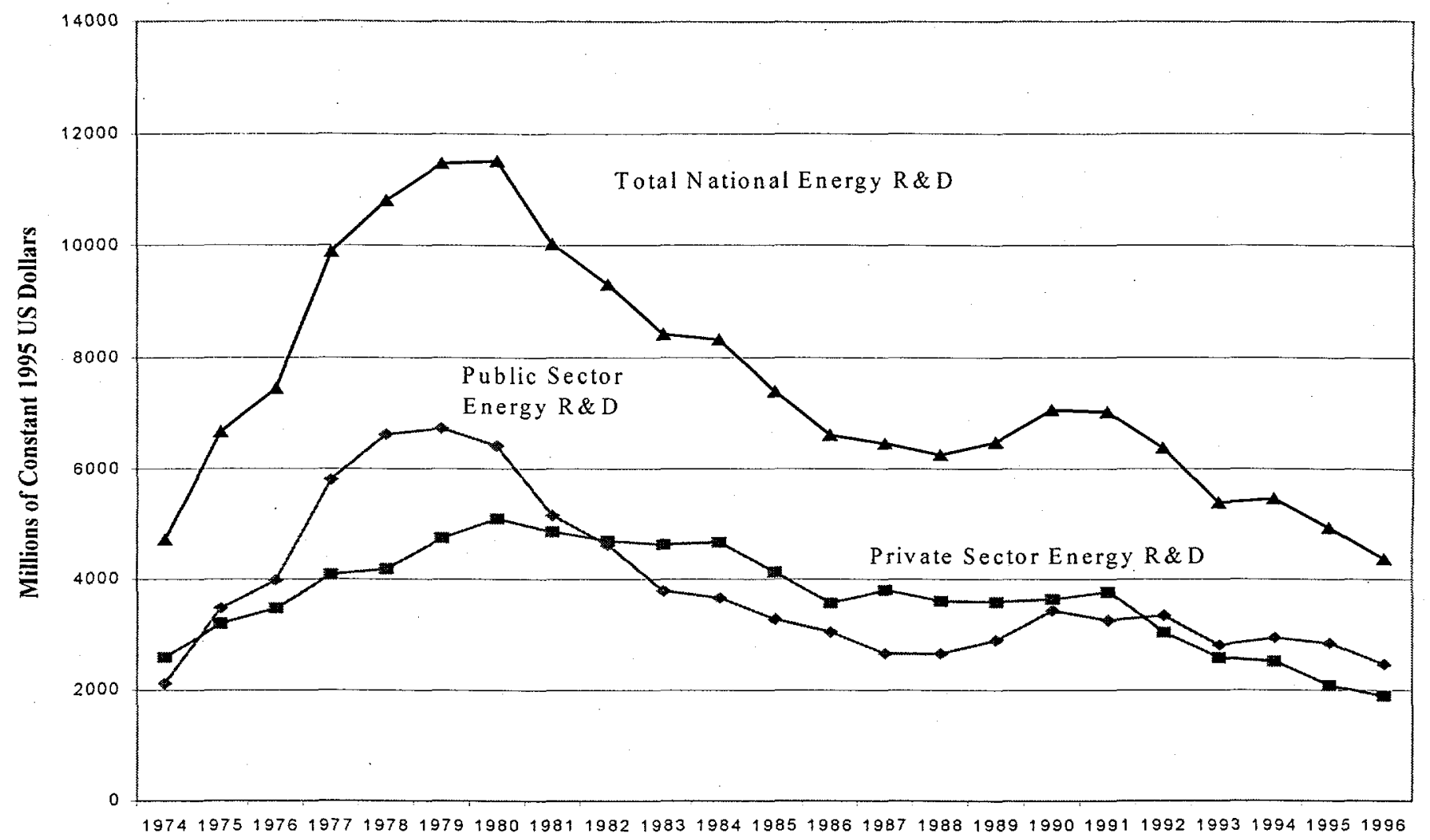

Sources: The data used here to describe private-sector energy R\&D investments is built upon a combination of three primary data sets. The first of these is the only official, broad-based US government survey of industrial R\&D expenditures $(23,400$ firms surveyed annually), which is carried out by the National Science Foundation in cooperation with the Department of Commerce's Bureau of the Census (NSF/Census). Biennially, this survey collects data on private sector funding of energy $R \& D$ performed by industrial firms with annual $R \& D$ budgets of over $\$ 1$ million. The other two data sets used here to describe private sector energy R\&D funding are historical funding data from the Electric Power Research Institute (EPRI) and the Gas Research Institute (GRI), two large nonprofit energy research organizations in the United States. It proved necessary to add in the energy R\&D carried out through EPRI and GRI, since the NSF/Census survey did not include work funded by or carried out by nonprofit entities, e.g., R\&D funded by an investor-owned electric utility but coordinated through EPRI would not be counted in the NSF/Census data set. See J.J. Dooley, US National Investment in Energy R\&D: 1974-1996 (PNNL-11788, Washington, DC: Pacific Northwest National Laboratory, December 1997).

\footnotetext{
${ }^{\mathrm{C}} \mathrm{JJ}$ Dooley. US National Investments in Energy R\&D: 1974-1996. Pacific Northwest National Laboratory. PNNL-1 1788. Washington, D.C. December 1997. This research was request by the White House Council of Economic Advisors and is published in the Economic Report of the President: 1998. Council of Economic Advisors. Washington, D.C. February 1998.
} 
Figure 5: US Federal Investments in Energy R\&D: 1985-1997

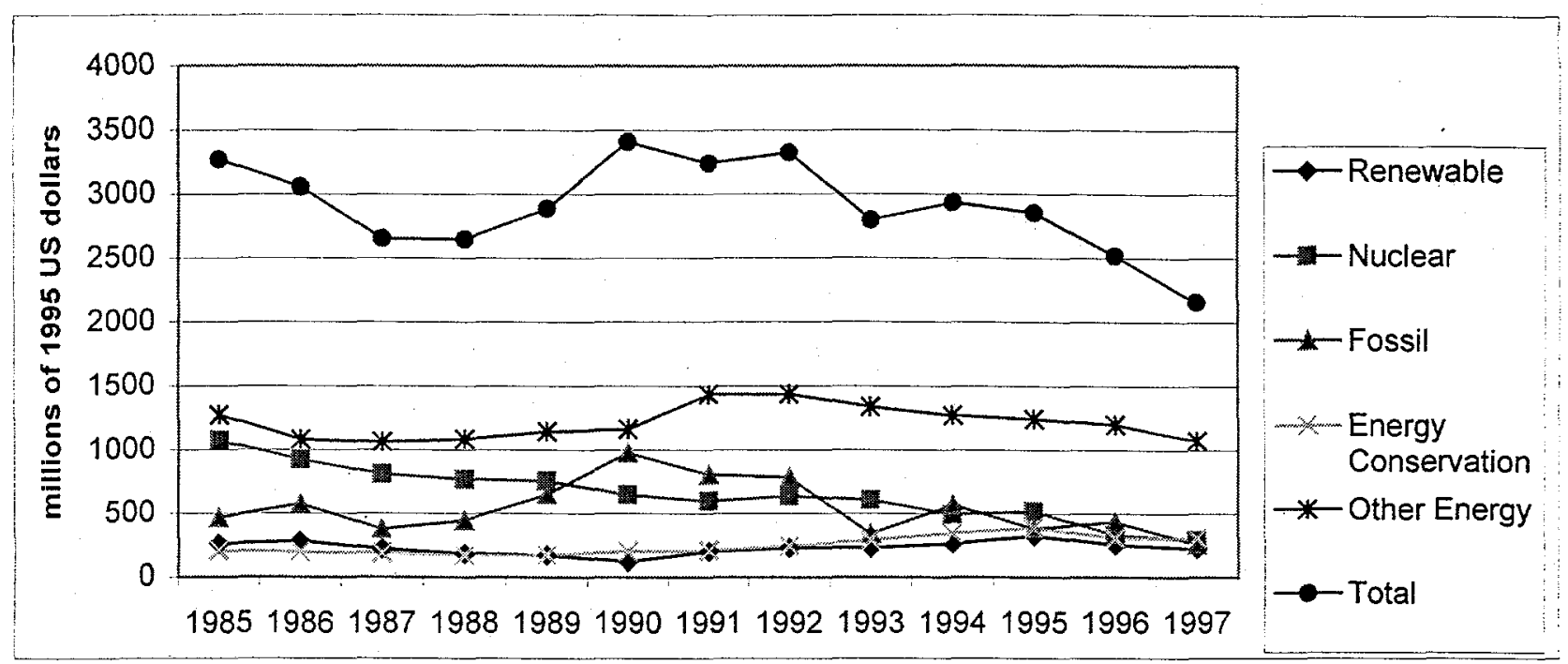

Sources: Ronald Meeks, Federal R\&D Funding by Budget Function: Fiscal Years 1996-98 (Special Report, NSF 98-301, Arlington, VA: National Science Foundation, Division of Science Resources Studies, 1997); National Science Foundation, Federal R\&D Funding by Budget Function: Fiscal Years 1994-96 (NSF 95-342, Arlington, VA: National Science Foundation, 1995); J.J. Dooley. "Unintended Consequences: Energy R\&D in Deregulated Market," Energy Policy (June 1998): 547-555.

Fossil Energy

FY1998 \$362.4 million

The US Department of Energy's Fossil Energy R\&D program is in the midst of a profound change in emphasis and direction. Since 1990, the program has seen its R\&D effort fall by more than $55 \%$ in real terms. The 20 -year $\$ 2.4$ billion industrially cost-shared Clean Coal Program has largely been terminated. ${ }^{31}$ In its place, the Office of Fossil Energy is seeking to expand its fuel cell program and is attempting to initiate long-term and more research-oriented programs in methane hydrate production and carbon dioxide capture and storage. While relatively new programs such as these represent a rather modest proportion of the overall research effort funded by this office, they do represent a new direction that the office has been urged to adopt so that its programs are more directly oriented to addressing the issue of climate change. ${ }^{32}$

The Fossil Energy Research program can be subdivided into four major program areas: coal R\&D, oil R\&D, gas R\&D, and an "other" category. The budget for the other category in FY1998 stood at $\$ 95.2$ million with the majority of these funds going towards program management and lesser amounts directed at environmental restoration $R \& D$, some advanced metallurgical process $\mathrm{R} \& \mathrm{D}$, and other cross-cutting research areas. ${ }^{33}$ A fuller explanation of the coal, oil and natural gas $R \& D$ programs is presented below.

\section{Coal R\&D}

\section{FY1998 $\$ 107.4$ million}

The majority ( $\$ 74$ million) of the funds in this program area allocated to the Advanced Power Systems program and are directed at research programs designed to develop higher efficiency coal combustion systems such as advanced pulverized coal technologies, indirectly fired cycles, gasification-combined cycles, and advanced pressurized fluidized bed reactors. The coal program also focuses ( $\$ 15.8$ million) on advanced "clean fuel technologies" needed for coal-to-liquids programs (i.e., direct and indirect liquefaction) as well as physical and chemical processes for 
cleaning coal prior to combustion. The last component of this coal program ( $\$ 17.6$ million) is a series of crosscutting research efforts to develop new materials, instrumentation and controls, and coal transport systems needed for a wide variety of coal consuming processes. Within the advanced power system program in FY1998 was the start of what is hoped to be a significant program in carbon dioxide capture and disposal. In FY1998, the Office of Fossil Energy funded the first 12 projects (each at approximately $\$ 50,000$ ) to develop innovative concepts for the carbon dioxide capture and disposal programs. The Office of Fossil Energy hopes to rapidly expand this program to point where its annual budget is at the tens of million dollars a year level. The ultimate goal of this program is to develop technologies through the proof-of-concept stage by 2005 and subsequently demonstrated at full scale by 2010 that could economically capture and sequester carbon dioxide. ${ }^{34}$

Natural Gas R\&D

FY1998 \$111.2 million

The bulk of the natural gas $R \& D$ program is directed at developing clean, high-efficiency electricity generation technologies fueled by natural gas. The two major focuses of this aspect of the program are the advanced gas turbines research program ( $\$ 45.0$ million) and the fuel cell program ( $\$ 40.2$ million). The natural gas R\&D program also funds some research ( $\$ 15$ million) directed at natural gas supply, storage, and processing technologies designed to ensure the longterm availability of the US gas supply. The program also funds ( $\$ 7.8$ million) a natural gas to liquids program designed to easily transform natural gas into more transportable liquid forms to serve as alternatives to oil-based transportation fuels. ${ }^{35}$ Starting with the FY1999 budget, the Office of Fossil Energy hopes to formally restart its methane hydrate research program. (DOE had a methane hydrate program that ran from 1982-1992.) The budget for this program will likely be quite modest in the first few years (less than a million dollars), but the Office of Fossil Energy hopes the program will rapidly grow to the tens of millions of dollar level to begin fulfilling the methane hydrate program"s goal of "commercial production of methane from hydrates by 2015. .36

Oil $R \& D$

FY1998 \$48.6 million

The Oil Technology Program focuses on developing technologies needed to keep US marginal oil fields in continuing production, advanced exploration (e.g., seismic imaging) technologies needed to identify new resources, and advanced production technologies (e.g., advanced drilling, completion, and stimulation technologies). The program also supports some research related to environmental protection and crosscutting oil production $R \& D{ }^{37}$

Nuclear (Fission and Fusion) R\&D

FY1998 \$273.6 million

Even though the United States has the largest number of operating nuclear reactors (109) delivering the largest capacity $(100,000 \mathrm{MW})$ in the world, the research and development underpinning the continued development of this energy source has been in serious decline for over a decade. ${ }^{38}$ Deep reductions have been felt by both of the major aspects of this program, fusion $R \& D$ and fission R\&D.

Fission $R \& D$

FY1998 \$ 66.9 million

Cumulative investments between 1979 and 1997 in fission reactor research sponsored by the US Department of Energy totaled $\$ 11.3$ billion (in constant 1997 dollars). ${ }^{39}$ However, since 1985 , US federal investments in nuclear fission R\&D have declined by $73 \%$ in real terms. The small US fission program funds the University Nuclear Science and Reactor program ( $\$ 7$ million), which supports the needed maintenance for an ever-decreasing number of university-based nuclear research reactors and associated educational activities. According to one estimate, undergraduate enrollment in nuclear engineering programs has fallen by $10 \%$ per year throughout 
the $1990 \mathrm{~s}^{40}$ This has resulted in there being only 30 operating university-based research reactors in 1999 , less than half the number that were in operation in the late $1970 \mathrm{~s}^{41}$ The program also supports ( $\$ 12$ million) research needed to extend the operating lifetimes of the current stock of US nuclear reactors ensuring their continued safe operation. The federal fission program also funds ( $\$ 40.5$ million) research on advanced radioisotope reactors for spacecraft. ${ }^{42}$

In FY1999, the Department of Energy was able to win Congressional support to begin a modest program ( $\$ 19$ million) to start a program to begin exploring the design of the next generation of nuclear power plants. ${ }^{43}$ Although a modest program to begin with, DOE hopes that this program will be the start to reverse the trend of the past years where there was no funding for research related to new reactor designs.

\section{Fusion R\&D}

FY1998 \$230 million

The fusion nuclear program's budget has been reduced drastically over the last decade. The most recent of these reductions occurred in 1996 when Congress reduced the programs budget by onethird and directed that the program change its focus from a program designed to make fusion a practical energy source by the end of the twentieth century to one that now is ostensibly focused on developing the science for fusion as a long-term energy source. The fusion program funds basic research to understand the behavior of plasmas, novel fusion energy system concepts, and the US participation in the ITER project. ${ }^{44}$

\section{Renewable Energy R\&D}

FY1998 \$341 million

Although federal support for renewable energy has remained relatively flat during the $1990 \mathrm{~s}$ (total funding in 1997 is only 9.4\% higher in inflation-adjusted terms than it was in 1990), there have recently been many calls for a dramatic expansion of the federal role to support the development of these technologies. The PCAST study suggested doubling federal funding for renewable energy $R \& D$, citing as justification evidence that these flat budgets have prevented the necessary growth in these programs to support needed fundamental research that would dramatically improve the performance of these systems and that utility deregulation in the United States is making it more difficult for private companies to sell these renewable energy systems and support their own internal R\&D programs. ${ }^{45}$. This suggestion to double federal resources for renewable energy $R \& D$ seems unlikely given outyear projections for these programs. This will then force further tradeoffs to be made (e.g., funding more near term research at the expense of more fundamental research) and the possibility of terminating less promising research programs (e.g., the US government has already terminated its ocean thermal energy conversion, solar pond, and wave energy R\&D projects on these grounds). ${ }^{46}$

\section{Solar Energy R\&D}

FY1998 \$70.4 million

The solar energy R\&D program funds a wide variety of research thrusts, including photovoltaic (PV) cells, solar thermal electric power plants, photoconversion processes, passive solar buildings, solar water and space heating systems, and solar resource data. Much of the entire solar energy R\&D program is cost shared with industry. The vast majority ( $\$ 65.4$ million) of the solar program's budget is directed towards photovoltaic research. This program focuses on developing various thin film PV systems and R\&D on ways to lower the manufacturing costs of these systems. In addition, the Office of Science (formerly the Office of Energy Research) funds basic research on understanding fundamental materials issues with these systems. The Solar Thermal program ( $\$ 16.5$ million) is focused on solar thermal electric systems which make electricity directly from the concentrated solar heat using conventional thermal power cycles. 
The biomass program is funded by two separate offices: the Office of Energy Efficiency and Renewable Energy funds the majority ( $\$ 58.8$ million) of the program and concentrates its work on biomass gassification and pyrolysis, and cleanup technologies for high temperature biogas. The program also is analyzing and developing specific crops for use as bioenergy feedstocks. The Office Science's Division of Energy Biosciences supports ( $\$ 38.6$ million) more fundamental basic research needed to provide a better understanding of basic biological processes associated with the capture, transformation, storage and utilization of energy in plants and microorganisms, such as photosynthesis, bioenergetics, primary and secondary metabolism, the synthesis and degradation of biopolymers such as lignin, anaerobic fermentations, genetic regulation of growth and development, thermophily (e.g., bacterial growth under high temperature), and other phenomena with the potential to impact biological energy production and conversion.

Wind Energy R\&D

FY1998 \$32.8 million

The wind energy $R \& D$ program focuses on fundamental engineering and technological issues associated with wind turbines and associated systems. The program also supports cost-shared research with industry to develop, test and deploy the next generation of wind energy systems. ${ }^{47}$

Geothermal Energy R\&D FY1998 \$29.0 million

The geothermal program is carried out on a cost-shared basis with US industry. The program focuses on developing and deploying the knowledge and technologies needed to locate and exploit geothermal resources including new drilling and seismic imaging technologies. The program is also developing new large-scale and smaller, distributed geothermal energy conversion systems. ${ }^{48}$

Hydrogen Energy R\&D

FY1998 \$19.1 million

The hydrogen program's overall goal is to improve the economics and reduce the environmental impacts associated with producing hydrogen. The program is working with industry to develop more economical and cleaner ways of producing hydrogen from methane, as well as funding more basic research geared towards producing hydrogen without having to use carbonaceous feedstocks, e.g, producing hydrogen directly from solar-powered electrolysis. The program is also working on technologies and systems needed to store and transport hydrogen as well as developing safe and cost effective fueling systems for hydrogen-powered vehicles.

\section{Electric Energy Systems and Storage R\&D}

FY1998 \$42.8 million

The electric energy systems and storage R\&D program has two principal focuses, research on high temperature superconductors (HTS) (\$32 million) and the development of advanced energy storage systems ( $\$ 3.9$ million). The high temperature superconductor aspect of this research program is focused on understanding how to manufacture wires and cables made from these typically very brittle HTS compounds and developing electrical motors, generators and transformers that would utilize these HTS components. The energy storage system R\&D program is designed to develop advanced components and system concepts (e.g., flywheels, high energy-density batteries, superconducting magnetic energy storage systems) for energy storage that will be needed if there is to be widespread adoption of many kinds of renewable energy systems. The program is also in its last year of funding ( $\$ 6.9$ million) research related to understanding the effects of electric and magnetic fields.

Energy Efficiency

FY1998 \$591 million

US federal investments in energy efficiency are directed at three sectors: buildings (both commercial and residential), industry and transportation. According to a recent review of US 
energy R\&D policy, cumulative federal investments in energy efficiency R\&D from 1978-1996 totaled $\$ 8$ billion. This federal investment coupled with complementary private sector investments are estimated to have reduced US energy bills by $\$ 150-200$ billion per year. ${ }^{50}$ Because of returns like these, federal investments in energy efficiency generally receive bipartisan support and this support has been responsible for the $53 \%$ real increase in the federal energy efficiency R\&D budgets since 1990.

Transportation Energy Efficiency

FY1998 \$193.3 million

The transportation research program focuses on ways to increase the fuel efficiency of automotive vehicles as well as heavy vehicles (trucks) and research needed to develop alternatively powered vehicles. In addition, the program also supports the development of crosscutting technologies such as lighter materials as well as deployment and testing of new transportation technologies. The Advanced Automotive Technology program ( $\$ 113.2$ million) is developing technologies needed for cleaner and more energy-efficient automobiles such as electric and hybrid technologies, advanced heat engines, fuel cells, alternative fuels, and advanced propulsion materials. ${ }^{51}$ The heavy vehicle program ( $\$ 25.6$ million) is working with industry to develop advanced heavy vehicle engines that would be capable of fuel switching as well as research to develop these alternative fuels (e.g., biodiesel fuels). The transportation program also has a significant research effort ( $\$ 35$ million) to develop advanced lightweight transportation materials and advanced high-temperature materials for vehicle applications. Technology deployment and demonstration programs ( $\$ 11.8$ million) are another focus of this program's crosscutting research.

\section{Industrial Energy Efficiency}

FY1998 \$136.2 million

The industrial energy efficiency program carries out $R \& D$ programs designed to reduce fuel consumption and pollution in the most energy- and waste-intensive industries by applying innovative technologies, such as cogeneration technologies; efficient steam systems; waste-toenergy systems; and electric motors and drives. The Office of Industrial Technologies has organized much of its research ( $\$ 53.1$ million) to focus on developing in collaboration with affected industries the technologies needed to improve energy efficiency in the seven most energy and waste intensive industries in the US. The seven "Industries of the Future" that are the focus of this program are petroleum refining, forest products, chemicals, steel, aluminum, metalcasting, and glass. The industrial energy efficiency program also funds ( $\$ 49.1$ million) more crosscutting research related to cogeneration and advanced materials that could be applicable to any number of industrial applications. Lastly, the program has significant ( $\$ 26.3$ million) efforts to demonstrate and deploy these technologies.

\section{Building Energy Efficiency}

FY1998 \$77.1 million

The buildings' energy efficiency program funds research related to (1) energy-efficient lighting and appliances, advanced heating and cooling equipment; designing new insulation and other weatherization retrofit materials; high-performance windows ( $\$ 27$ million); (2) better building design techniques ( $\$ 23$ million) and building and appliance codes and standards ( $\$ 14.4$ million).

Federal Energy Management

FY1998 \$19.8 million

The Federal Energy Management Program carries out research and planning activities designed to advance the deployment of energy efficient, water saving and renewable energy technologies into federal buildings and federal installations. 


\section{Other Energy-Related R\&D Programs}

\section{Basic Energy Sciences}

FY1998 \$660.3 million

The Office of Basic Energy Sciences within the Office of Energy Research supports basic scientific research to support and underpin the advanced energy technologies being developed by the Department of Energy's other offices described above. The office also funds basic research geared towards understanding and where possible mitigating the environmental impacts of energy use. The office also constructs and operates major scientific user facilities that are used by thousands of scientists from universities, national laboratories, and industrial laboratories to explore the fundamental behavior of materials. The Office funds a wide array of basic materials research (\$391 million), chemical sciences ( $\$ 200$ million), engineering and geosciences $(\$ 41.2$ million) and energy bioscience research ( $\$ 27.4$ million).

Civilian High-Level Radioactive Waste FY1998 \$346 million

The Office of Civilian Radioactive Waste Management primarily focuses its research on the characterization and preparation of the Yucca Mountain site so that it can be ready to open in 2010 as the nation's repository for civilian reactor wastes. ${ }^{52}$ 
'Central Intelligence Agency (CIA), "World Factbook 1997."

http://www.odci.gov/cia/publications/factbook/index.html

${ }^{2}$ CIA, "World Factbook 1997."

${ }^{3}$ National Science Board, Science \& Engineering Indicators - 1998. Arlington, VA: National Science Foundation, 1998 (NSB 98-1).

${ }^{4}$ National Science Board, Science \& Engineering Indicators - 1998.

${ }^{5}$ National Science Board, Science \& Engineering Indicators - 1998.

${ }^{6}$ Ibid.

${ }^{3}$ Ibid.

${ }^{8}$ Ibid.

${ }^{9}$ National Science Foundation, "Data Brief: 1995 US Industrial R\&D Rises, NSF Survey Statistics Expanded to Emphasize Role of Nonmanufacturing Industries (NSF 97-332, December 16, 1997. http://www.nsf.gov/sbe/srs/databrf/sdb97332.htm).

${ }^{10}$ T. Stundt J. and Duga, "Strong US Economy Drives Continued R\&D Growth," R\&D Magazine (1999).

${ }^{11}$ National Science Foundation. "Research and Development in Industry: 1997 Early Release Tables" (1999) http://www.nsf.gov/sbe/srs/srs99411/start.htm

${ }_{12}$ National Science Foundation, "Data Brief: 1995 US Industrial R\&D Rises, NSF Survey Statistics Expanded to Emphasize Role of Nonmanufacturing Industries" (NSF 97-332, December 16, 1997 http://www.nsf.gov/sbe/srs/databrf/sdb97332.htm)

${ }^{13}$ Mark Crawford, "First, Rockefeller Advance R\&D Spending Bill." New Technology Week (June 22, 1998): 3 .

14 "AAAS Analysis of Outyear Projections for R\&D in the FY 2000 Budget," American Association for the Advancement of Science's AAAS R\&D Budget and Policy Project (March 9, 1999, http://www.aaas.org/spp/dspp/rd/fy00.htm)

${ }^{15}$ National Science Board, Science \& Engineering Indicators - 1998.

${ }^{16}$ Ronald Meeks, Federal R\&D Funding by Budget Function: Fiscal Years 1996-98.

17 "AAAS Analysis of Outyear Projections for R\&D in the FY 2000 Budget."

${ }^{18}$ National Science Board, Science \& Engineering Indicators - 1998.

${ }^{19}$ Ronald Meeks, Federal R\&D Funding by Budget Function: Fiscal Years 1996-98.

${ }^{20}$ Energy Information Agency, "United States of America: Country Analysis Brief" (April 1998 http://www.eia.doe.gov/emeu/cabs/usa.html).

${ }^{21}$ The Council of Economic Advisors, The Kyoto Protocol and the President's Policies to Address Climate Change: Administration Economic Analysis (Washington, DC: July.1998).

${ }^{22}$ J.J. Dooley, "Unintended Consequences: Energy R\&D in Deregulated Market," Energy Policy (June 1998): 547-555.

${ }^{23}$ US Department of Energy, Energy Information Agency, "United States of America: Country Analysis Brief" (April 1998. http://www.eia.doe.gov/emeu/cabs/usa.html).

${ }^{24}$ US Department of Energy, Energy Information Agency, "Status of State Electric Utility Deregulation Activity as of April 1, 1999" (April 1999. http://www.eia.doe.gov/cneaf/electricity/chg_str/tab5rev.html). ${ }^{25}$ US Department of Energy, Energy Information Agency. "United States of America: Country Analysis Brief."

${ }^{26}$ Ibid.

${ }^{27}$ Ibid.

${ }^{28}$ US Department of Energy, Energy Information Agency, "United States of America: Country Analysis Brief" (April 1998. http://www.eia.doe.gov/emeu/cabs/usa.html); General Accounting Office, "Department of Energy: Proposed Budget in Support of the President's Climate Change Technology Initiative" (Letter Report, 04/10/98, GAO/RCED-98-147, Washington, DC); US Department of Energy, Energy Information Agency, Annual Energy Outlook 1998 (Washington, DC, December 18, 1997).

${ }^{29}$ JJ Dooley. "Unintended Consequences: Energy R\&D in Deregulated Market."

${ }^{30}$ John Holdren et al., Federal Energy Research and Development for the Challenges of the Twenty-first Century (Report of the Energy Research and Development Panel of the President's Committee of Advisors on Science and Technology, Washington, DC: September 30, 1997).

${ }^{31}$ Ibid.

${ }^{32}$ Ibid. 
${ }^{3333}$ US Department of Energy, Office of Fossil Energy, "FY 1999 Budget Request to Congress: Budget Table" (http://www.fe.doe.gov/budget/99table.html).

${ }^{34}$ US Department of Energy, Office of Fossil Energy, "DOE Selects Potential Breakthrough Approaches For Removing Greenhouse Gases from Ecosystem" (Fossil Energy Techline, April 29, 1998, http://www.fe.doe.gov/techline/tl_novelseq.html).

${ }^{35}$ US Department of Energy, Office of Fossil Energy, "FY 1999 Budget Request to Congress: Budget Table"; US Department of Energy, Office of Fossil Energy, "Natural Gas Technology: New Options for an Abundant US Resource" (http://www.fe.doe.gov/oil_gas/natgas.html).

${ }^{36}$ US Department of Energy, Office of Fossil Energy, A Strategy for Methane Hydrates Research \& Development (DOE/FE-0378, Washington, DC: August 1998).

${ }^{37}$ US Department of Energy, Office of Fossil Energy, "FY 1999 Budget Request to Congress: Budget Table"; John Holdren et al., Federal Energy Research and Development for the Challenges of the Twentyfirst Century.

${ }^{38}$ John Holdren et al., Federal Energy Research and Development for the Challenges of the Twenty-first Century.

${ }^{39} \mathrm{Ibid}$.

${ }^{40}$ David Malakoff, "Nuclear Power: New DOE Research Program to Boost Sagging Industry" Science 282 (December 11, 1998) 1980-1981.

41 "Meltdown," Science 283 (February 26, 1999) 1237.

${ }^{42}$ US Department of Energy, Office on Nuclear Energy, Science and Technology, "FY1998 and FY1999 Budget (Excludes Naval Reactors)" (http://www.ne.doe.gov/org/budget.stm)

${ }^{43}$ David Malakoff, "Nuclear Power: New DOE Research Program to Boost Sagging Industry."

${ }^{44}$ US Department of Energy, Office of Energy Research, "President's FY1999 Budget Request for the Office of Energy Research" (http://www.cfo.doe.gov/budget/99budget/science/execsum.pdf).

${ }^{45}$ John Holdren et al., Federal Energy Research and Development for the Challenges of the Twenty-first Century.

${ }^{46}$ Ibid.

${ }^{47}$ US Department of Energy, Office of Energy Efficiency and Renewable Energy, "President's FY1999 Budget Request for the Office of Energy Research"

(http://www.cfo.doe.gov/budget/99budget/esrd/ee/srrtl.pdf)

${ }^{48}$ Ibid.

${ }^{49} \mathrm{Ibid}$.

${ }^{50}$ John Holdren et al., Federal Energy Research and Development for the Challenges of the Twenty-first Century.

${ }^{51}$ US Department of Energy, Office of Advanced Automotive Technologies (http://www.ott.doe.gov/oaat)

52 US Department of Energy, Office of Civilian Radioactive Waste Management, "Fiscal Year 1999 Budget Request Summary, February 1998". (http://www.rw.doe.gov/pages/budget/execSumBR99.pdf, March 17, 1998); John Holdren et al., Federal Energy Research and Development for the Challenges of the Twentyfirst Century. 